\title{
Крот и колотушка: Исламское государство и Аль-Каида в «Тридцатилетней войне» на Ближнем Востоке
}

\section{Ларс Эрслев Андерсен}

Датский институт международных исследований, $h t t p: / / w w w . d i i s . d k$

Резюме: В этой работе сделан анализ развития событий, связанных с Аль-Каидой и Исламским государством, в контексте войны с терроризмом. Иракская война 2003-2010, в том числе и контрповстанческая стратегия, реализуемая в Ираке после 2007 года, в сочетании с развитием политических событий в Ираке после вывода войск США в конце 2011 года, рассматриваются как рассадник для Исламского государства в Ираке и, таким образом, и для создания Фронта Нусра (Аль-Каида) в Сирии. В этой главе показано, что без политического прогресса, обусловленного надежными государствами на Арабском Ближнем Востоке, в обозримом будущем не видно решения, которое приведет к окончанию конфликтов и войн в этом регионе.

Ключевые слова: Ирак, Сирия, Исламское государство, Аль-Каида, ан-Нусра, война с терроризмом.

\section{Введение}

В садах «Тиволи» в Копенгагене есть аркадная игра, которая называется «Пристукни крота». Смысл игры в том, кто сможет ударить колотушкой наибольшее число кротов в кратчайшее время. Вы не можете выиграть у кротов, поскольку они продолжают появляться из своих нор, но вы можете ударить наибольшее число кротов в кратчайшее время. Если принять, что кроты символизируют Аль-Каиду (АК) и Исламское государство (ИГ), а колотушка символизирует военный инструмент, выбранный Западом для нанесения поражения этим двум террористическим группировкам на Ближнем Востоке, игра «Пристукни крота» очень хорошо иллюстрирует то, что колотушка, военный инструмент, не может выиграть против кротов, 
т.е. против Аль-Каиды и Исламского государства. Для того, чтобы игра продолжалась, в машину надо опускать монеты. Очевидно, большим вопросом войны против терроризма является вопрос, что позволяет АК и ИГ продолжать действовать? Обескураживающим является заключение, что частично объяснение состоит в том, что война против терроризма на Ближнем Востоке и в других местах организована с использованием молота. Другим не менее важным объяснением является борьба за власть, политическое влияние и контроль над ресурсами в авторитарных государствах Ближнего Востока, которая в сочетании с подстрекаемым двумя региональными "сверхсилами», Саудовской Аравией и Ираном, конфликтом между шиитами и суннитами, разрывает Ближний Восток на части. Эта ситуация похожа на ближневосточное воссоздание Тридцатилетней войны в Европе.

\section{Текущий статус}

Однако война против АК и движения «Талибан» и против диктаторов Ближнего Востока, Саддама Хусейна и Муаммара Каддафи, способствовали разгоранию ближневосточного конфликта. Это и есть урок, извлеченный из 15 лет войны против терроризма на Ближнем Востоке. Война началась с бомбардировок тренировочных лагерей АК в горах Тора Бора в Афганистане, она продолжилась в войнах в Ираке и Ливии, и сейчас снова вернулась в Ирак и как новая война в Сирии. АК тоже вернулась, в частности в Сирию и Йемен, но так же и в другие страны. Кроме того, в такие области, как Африка, Йемен, Афганистан и Пакистан, распростерлось Исламское государство, которое создало тренировочные лагеря в Сирии для подготовки европейцев, которые возвращаются в Европу в качестве террористов, как мы видели в Париже в ноябре 2015 и в Брюсселе в марте 2016. Стоит отметить, что война против терроризма способствовала переносу тренировочных лагерей из Афганистана в Сирию, т.е. они стали ближе к Европе.

Таким образом, в 2016 году мы можем прийти к заключению, что АК, которую многие люди, в том числе автор этой статьи, после уничтожения Усамы Бен Ладена в 2011 году считали побежденной, возможно, снова становится опасной глобальной террористической организацией с заявленным намерением наносить удары по объектам и на Западе. После смерти Усамы Бен Ладена в мае 2011 и уничтожения многих печально известных лидеров АК в ходе военных действий, проводимых с помощью беспилотных летательных аппаратов, чья интенсивность была усилена, когда президентом в 2009 году стал Барак Обама, многие люди решили, что АК побеждена и поет свою лебединую песню. ${ }^{1}$ Однако кое-кто предупре-

1 Смотри, к примеру, Peter L. Bergen, “Epilogue: The Twilight of Al-Qaeda," in Peter L. Bergen, Manhunt. The Ten-Year Search for Bin Laden from 9/11 to Abbottabad (New York: Broadway Paperbacks, 2012). 
ждал, что АК может вернуться, и что небольшие сети АК, все еще существующие на Ближнем Востоке, при определенных обстоятельствах и в определенном контексте, могут снова получить импульс к действию. ${ }^{2}$ Они оказались правы, хотя те, кто заявляли, что АК умирает, ошибались не полностью. Сегодня повестку дня определяет совсем другая АК по сравнению с той, что доминировала под руководством их великого лидера, Усамы Бен Ладена. Смертный приговор АК оказался действительным в отношении ее высшего руководства. Айман аз-Завахири является последним из больших лидеров, которые сформировали АК, но сегодня у него нет той власти, которой он располагал в дни расцвета АК.

Завахири все еще делает заявления, всегда ссылаясь на условия в Сирии, и рассылает письма с приказами лидерам региональных групп АК, на-

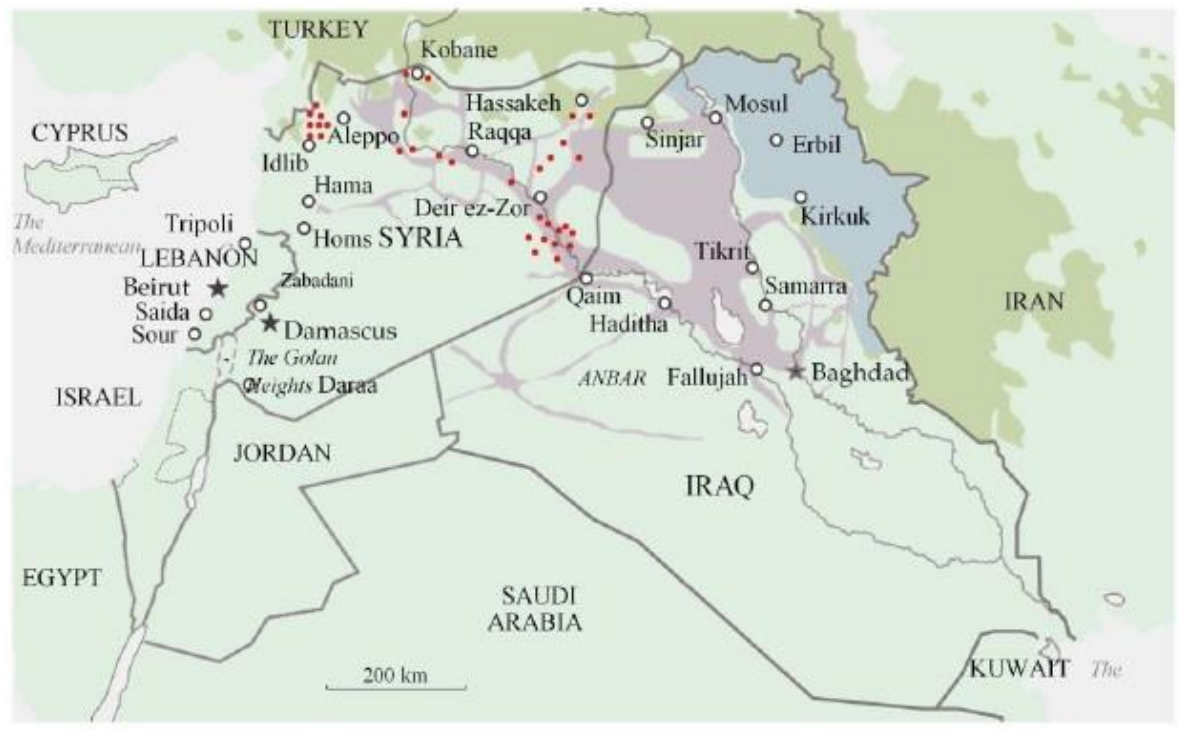

Источники: Институт исспедования войны; Д-р М. Изади на Gulf2000/Columbia University; The Economist

$$
\begin{aligned}
& \text { Области в которых действует ИГ } \\
& \text { Области населенные курдами } \\
& \text { Области под контролем курдов } \\
& \text { Воздушные удары США и коалиции }
\end{aligned}
$$

Фигура 1: Карта Сирии и Ирака.

2 Katherine L. Zimmerman, “Testimony: AQAP's Role in the al Qaeda Network: Statement before the House Committee on Homeland Security Subcommittee on Counterterrorism and Intelligence on "Understanding the Threat to the Homeland from AQAP," American Enterprise Institute for Public Policy Research (AEI), 18 September 2013, доступно на http://www.criticalthreats.org/al-qaeda/zimmerman-testimonyaqaps-role-al-qaeda-network-september-18-2013. 
пример Абу Мухаммад аз-Джулани, лидеру Джабхат ан-Нусра, который любезно передает письма своим людям, но в своих собственных заявлениях и интервью (напр. Арабскому спутниковому каналу Аль-Джазира) не стесняется поднимать вопросы, касающиеся этих самых приказов. Однако, обычно аз-Джулани проявляет лояльность к стареющему лидеру АК. Когда в июне 2015 года Завахири предположил, что Джабхат ан-Нусра (также известная как Фронт ан-Нусра) следует перестать планировать террористические нападения на Западе, аз-Джулани его поддержал, заявив на АльДжазире, что Джабхат ан-Нусра «в настоящее время не рассматривают Сирию как базу для нападений на Западе». Однако он дополнил, что цель в Сирии «не только в том, чтобы освободиться от режима Башара Асада, но и нечто большее», т.е. создать основанное на Шариате исламское государство, а в долгосрочном плане халифат (цитаты из работ Чарльза Листера). ${ }^{3}$ Из Йемена и Афганистана в Сирию приехала таинственная группа функционеров АК, которые создали там тайную организацию. Согласно Чарльзу Листеру, исследователю по проблемам Сирии, собственные люди Джабхат ан-Нусра называют эту группу «Волки», а Цру дало ей название «Группа Хорасан». ${ }^{4}$ Это как раз та группа, террористические планы которой против Запада хотел остановить Завахири, потому что деятельность группы стала причиной бомбардировок США в провинции Идлиб в Сирии, где базируется Джабхат ан-Нусра.

Кроме как к уничтожению Джабхат ан-Нусра в борьбе против Башара Асада, которая является, по мнению Завахири, первостепенной задачей АК в Сирии, бомбардировки США приводят к жертвам среди гражданского населения, что увеличивает риск того, что местные жители станут поддерживать другие группировки, а не Джабхат ан-Нусра. Однако аз-Джулани не остановил «Волков», поскольку их специфические умения могут понадобиться в будущем, например, если Запад усилит войну против АК (т.е. Фронта ан-Нусра) в Сирии.

Оперативное влияние Усамы Бен Ладена было уже на исходе в его последние годы, проведенные в добровольно выбранной им самим ссылке в Абботтабаде, Пакистан, где он скрывался от агентов США и передового спутникового наблюдения. Бен Ладен связывался с региональными лидерами АК в Северной Африке, Африканском роге, в Йемене и другими через курьера, но они редко следовали его советам и приказам. ${ }^{5}$ По мере того,

3 Эта работа многим обязана очень подробному представлению, основанному на первоисточниках, личным интервью и обширным знаниям по Сирии и джихадистским сетям Чарльза Листера: Charles Lister, The Syrian Jihad. Al-Qaeda, The Islamic State and the Evolution of an Insurgency (Oxford: Oxford University Press, 2015).

4 Lister, The Syrian Jihad, 201.

5 Nelly Lahoud, Stuart Caudill, Liam Collins, Gabriel Koehler-Derrick, Don Rassler, and Muhammad al-'Ubaydi, Letters from Abbottabad: Bin Laden Sidelined? (West Point, NY: The Combating Terrorism Center at West Point, May 2012), доступно на https://www.ctc.usma.edu/posts/letters-from-abbottabad-bin-ladin-sidelined. 
как последствия американской кампании с беспилотными летательными аппаратами стали приводить к распаду высшего руководства АК, стали расти авторитет и самостоятельность региональных лидеров, внимание которых было сфокусировано на региональных конфликтах, в которых участвовали их группы. С ослабеванием центрального руководства глобальные террористические действия АК - и таким образом, «экзистенциальная угроза», каковой являлась эта организация для американцев, были минимизированы и трансформированы в региональный терроризм, который не являлся прямой угрозой для США или для Европы. Силу, которую приобрела АК в Сирии, сейчас уже приводит к реальной опасности, а в долгосрочном плане эта организация снова может стать глобальной угрозой. Частично причиной этому является мономаниакальная война против ИГ, в тени которой АК приобретает поддержку и набирает силу, что мы и наблюдали, когда Россия начала свое наступление в Сирии в сентябре 2015 года. Хотя АК сейчас очень отличается от прежней Ак - с менее централизованным управлением, с более региональной ориентацией и с такими новыми именами, как Джабхат ан-Нусра - она снова в игре с новой стратегией, которая может быть даже более опасной для Ближнего Востока и для Запада, чем старая централизованно управляемая стратегия при Усаме Бен Ладене, которая на первом месте была направлена против США. Новая стратегия направлена на устранение этой сверхсилы с Ближнего Востока.

15 лет после начала войны с терроризмом, с возвращением АК и ИГ, которые хотя и находятся под давлением в Ираке и Сирии, приобретают влияние в других местах и продемонстрировали свое намерение и способность организовывать террористические действия в Европе, террористическая угроза, похоже, постепенно усиливается. В этой работе рассмотрена история и предпосылки ИГ, обрисовано развитие и дана оценка АК за последние пять лет.

Изменение АК, в которой региональные подразделения становятся более независимыми от центрального руководства АК, хорошо иллюстрируется официальным разрывом Джабхат ан-Нусра с АК в конце июля 2016 года. ${ }^{6}$ Давно ходили слухи, как минимум с мая 2016, что Джабхат ан-Нусра, самая сильная повстанческая милиция в Сирии, отделится от АК для того, чтобы действовать более гибко в отношении других исламистских повстанческих групп в Сирии. До последнего времени эти группы (официально) воздерживались от объединения сил с Джабхат ан-Нусра из-за связи этой группировки с АК. Связь с АК мешает участию в переговорах по прекращению огня, поскольку международные игроки не будут вести переговоры с группировками АК. В мае 2016 ал-Завахири объявил, что он не

6 «Лидер ан-Нусра Джулани объявил о выходе из Аль-Каиды. Аль-Джазира получила эксклюзивную видеозапись Абу Мохаммеда ал-Джулани, в которой он говорит, что название группы было изменено на Джабхат Фатх аль-Шам», Аль-Джазира, 29 июля 2016. 
возражает против отделения Джабхат ан-Нусра от АК и концентрирования ее деятельности на войне в Сирии. Однако он подчеркнул, что у этих двух группировок остается общая цель - создать халифат. В июле 2016 руководители Джабхат ан-Нусра объявили, что группировка порвала с АК и что меняет свое название на Джабхат Фатх аль-Шам. В этой работе рассматривается развитие Джабхат ан-Нусра до ее выхода из АК в июле 2016 года.

\section{Иракская война}

Война в Ираке, в частности, является ключом к пониманию ситуации, развивающейся в настоящее время в Ираке и в Сирии, и таким образом, к пониманию того, почему ИГ и АК вернулись в качестве глобальных террористических угроз после того, как примерно в 2011 году угроза казалась почти устраненной.

Когда в 2000 году Башар Асад перенял руль власти после своего отца, сирийские службы безопасности попытались расширить влияние Сирии, начав устанавливать контакты с разными исламистскими сетями и группами АК, которые появлялись в пограничной области между Ираком и Сирией. Идея состояла в том, чтобы, с одной стороны, сделать жизнь американцев в Ираке возможно наиболее тяжелой в соответствии с предположением, что «если они воюют там, то здесь они нас оставят в покое», и с другой стороны, отклонить внимание от внутренних проблем и экспортировать джихадистов в Ирак. Когда в марте 2003 года началась война в Ираке, исламистские группировки и сети в Сирии стали ключевыми игроками в вербовке иностранных боевиков, в частности для повстанческого движения против коалиции под руководством США. Приграничная с Ираком территория Сирии стала центром организации трансграничного трафика и зоной для создания тренировочных лагерей. Несколько из основных операций в Ираке были организованы сетями в Сирии. Сирийские службы безопасности позволили этому случиться, но они в очень малой степени контролировали развитие событий. ${ }^{7}$

Схожим образом, в Ираке при Саддаме Хуссейне иракские службы разведки для реализации своих интересов пытались использовать вооруженные исламистские группировки. 8 Это означало, что до того как началась война в 2003 году, уже существовали связи между сирийской и иракской разведкой с одной стороны, и джихадистскими группами с другой. Эти связи подверглись дальнейшей консолидации, когда офицеры Саддама Хуссейна бежали в Сирию в начале войны после того, как Поль Бремер, глава временной коалиционной администрации в Ираке, издал указ о расформировании иракской армии. Таким образом, Сирия играла центральную роль в привлечении иностранных боевиков в Ирак. Кроме того,

7 Lister, The Syrian Jihad, 31ff.

8 Amatzia Baram, Saddam Husayn and Islam, 1968-2003. Ba'thi Iraq from Secularism to Faith (Washington, DC: Woodrow Wilson Center Press, 2014). 
иракские повстанцы могли находить убежище в Сирии и возвращаться в провинцию Анбар. Подобная динамика через пакистано-афганскую границу имела место с разными сетями движения «Талибан» и Аль-Каиды.

Так как контрповстанческие операции США с 2007 по 2008 год на деле существенно ограничили насилие в иракской провинции Анбар, и Аль-Каида в Ираке (АКИ) оказалась под сильным влиянием своих членов, бежавших в Сирию, угроза со стороны этих сетей начала беспокоить сирийский режим, который постепенно отказался от стратегии невмешательства в отношении джихадистов и подверг заключению сотни людей, ответственных за переправку иностранных боевиков в Ирак. По мнению Чарльза Листера и других исследователей, это те люди, которых Башар Асад амнистировал и выпустил из заключения в марте и мае 2011 года, когда начались демонстрации в Сирии. Вероятно, Асад вознамеривался использовать этих людей для того, чтобы представить сирийское восстание как «находящееся под контролем международных террористов», но вместо этого он реактивировал сети, которые были особенно эффективными в привлечении иностранных боевиков к повстанческому движению в Ираке, и сейчас они обернулись против него и правительства в Дамаске. Используя в качестве базы город Аль-Забадани на северо-востоке от Дамаска, быстро и эффективно были созданы исламистские повстанческие группы, и они привлекли многих сочувствующих, которые обернулись против режима Асада, начав совершать вооруженные нападения, оказавшиеся для режима в Дамаске полной неожиданностью. ${ }^{9}$

Нарратив Башара Асада, что за сирийским восстанием стоят иностранные террористы, имел неконтролируемый обратный эффект с тяжелыми последствиями. С этого и начинается история Джабхат ан-Нусра, АК в Сирии. Однако в действительности, иракская группировка Исламское государство в Ираке (ИГИ) послала Джулани в Сирию чтобы создавать Фронт ан-Нусра. Прежде, чем мы продолжим с Аль-Каидой в Сирии, необходимо рассказать вкратце о ситуации в Ираке.

\section{ИГ имеет глубокие корни в Ираке}

Еще до захвата Мосула ИГИЛ в июне 2014 года имелось много признаков, что развивается новая глобальная террористическая угроза. Эти признаки основывались на двух моментах - политической ситуации в Ираке и Арабской весне в 2011 году. Однако это развитие событий недооценивалось или полностью пренебрегалось политиками, СМИ и службами разведки, которые выражали уверенность, что иракское правительство способно держать ИГИ под контролем.

ИГИ, наоборот, внимательно ведет учет деятельности группы, и информация о них регулярно распространяется в форме заявлений и ежегодных

9 Lister, The Syrian Jihad, 54. 
Ларс Эрслев Андерсен, Connections QJ 16, № 1 (2017): 7-27

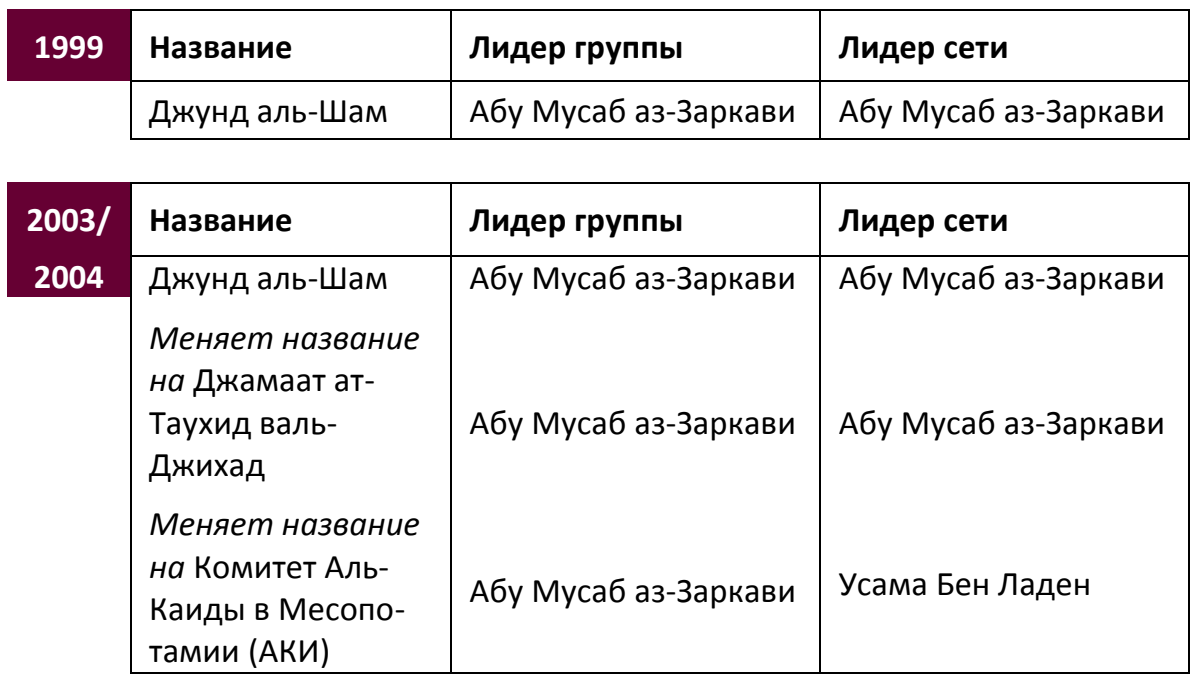

Аз-Заркави умирает

\begin{tabular}{|c|c|c|c|}
\hline 2006 & Название & Лидер группы & Лидер сети \\
\hline & $\begin{array}{l}\text { АКИ } \\
\text { Слияние АКИ и } 7 \\
\text { других групп Ис- } \\
\text { ламского государ- } \\
\text { ства в Ираке } \\
\text { (ИГИ): } \\
\text { Меджлис Шура } \\
\text { Муджахидин } \\
\text { (МУМ) } \\
\text { Меняет название } \\
\text { на Исламское } \\
\text { государство в } \\
\text { Ираке (ИГИ) = АКИ }\end{array}$ & $\begin{array}{l}\text { Абу Омар аль- } \\
\text { Багдади } \\
\text { Абу Омар аль- } \\
\text { Багдади }\end{array}$ & $\begin{array}{l}\text { Усама Бен Ладен } \\
\text { Усама Бен Ладен }\end{array}$ \\
\hline
\end{tabular}

Абу Омар и Абу Хамза умирают

\begin{tabular}{|l|l|l|l|}
\hline 2010 & Название & Лидер группы & Лидер сети \\
\hline \multirow{2}{*}{ АКИ / ИГИ } & Абу Бакр аль-Багдади & Усама Бен Ладен \\
\cline { 2 - 4 }
\end{tabular}

\begin{tabular}{|l|l|l|l|}
2011 & Название & Лидер группы & Лидер сети \\
\hline АКИ / ИГИ & Абу Бакр аль-Багдади & Айман аль-Завахири \\
\hline
\end{tabular}


ИГ и Аль-Каида в «Тридцатилетней войне» на Ближнем Востоке

\begin{tabular}{|l|l|l|l|}
2012 & Название & Лидер группы & Лидер сети \\
\hline Джабхат ан-Нусра & $\begin{array}{l}\text { Абу Мухаммад аль- } \\
\text { Джулани }\end{array}$ & $\begin{array}{l}\text { Абу Бакр аль-Багдади } \\
\text { / Айман аль-Завахири }\end{array}$ \\
\hline
\end{tabular}

Вспыхивает конфликт между ИГИ и АК

\begin{tabular}{|c|c|c|c|}
\hline 2013 & Название & Лидер группы & Лидер сети \\
\hline & $\begin{array}{l}\text { Исламское государ- } \\
\text { ство в Ираке } \\
\text { (аль-Багдади: слия- } \\
\text { ние ан-Нусра и ИгИ) } \\
\text { (аль-Завахири/аль- } \\
\text { Джулани: Джабхат } \\
\text { ан-Нусра) }\end{array}$ & $\begin{array}{l}\text { Абу Мухаммад аль- } \\
\text { Джулани } \\
\text { Абу Мухаммад аль- } \\
\text { Джулани }\end{array}$ & $\begin{array}{l}\text { Абу Бакр аль-Багдади } \\
\text { Айман аль-Завахири }\end{array}$ \\
\hline
\end{tabular}

Разрыв между ИГИЛ и АК

\begin{tabular}{|l|l|l|l|}
2014 & Лидер группы & Лидер сети \\
\hline $\begin{array}{l}\text { Исламское государ- } \\
\begin{array}{l}\text { ство/ Исламский } \\
\text { халифат }\end{array}\end{array}$ & Абу Бакр аль-Багдади \\
\hline
\end{tabular}

Фигура 2: «Семейное дерево» Исламского государства.

публикаций. В то же время, местные журналисты выразили свою озабоченность все более нарастающим могуществом и влиянием группировки в суннитских районах Ирака, в том числе в Мосуле, который стал центром власти для ИГИ после 2010 года.

После 2010 года ИГИ управляется строго и автократически Абу Бакр альБагдади (Ибрагим бен Аввад бен Ибрагим аль-Барди аль-Радави аль-Хуссейни аль-Самарраи) на пару со вторым человеком в командовании, Хаджи Бакр (Самир Абд Мухаммад аль-Клифави), у которого за спиной карьера полковника службы военной разведки при Саддаме Хуссейне. Хаджи Бакр был убит в январе 2014 года в маленьком городке в Сирии севернее Алеппо. ИГИ сформировало альянс с другими группами в ярости от своей маргинализации в плане политической власти: сначала в результате инвазии под руководством США с 2003 года, а затем иракским премьерминистром, Нури аль-Малики, который систематически мешал мусульманам-суннитам получить политическую власть, в том числе «Сынам Ирака», 
которые помогли его правительству и США подавить АКИ в периоде 20072010. ${ }^{10}$

История формирования ИГ начинается еще в 1999 году, когда иорданский джихадист, Абу Мусаб аль-Заркави (Ахмад Фадеел аль-Назал аль-Халиль) был выпущен из тюрьмы в Иордании. ${ }^{11}$ В тюрьме он познакомился с Абу Мухаммад аль-Макдиси, ${ }^{12}$ знатоком ислама иордано-палестинского происхождения, который вдохновил жестокого уголовника-головореза, аль-Заркави, на джихад, сфокусированный в основном на Иорданию, Ирак, Сирию и Палестину (Левант). В 2004 году между Макдиси и аль-Заркави произошел конфликт из-за войны аль-Заркави с мусульманами шиитами. Аль-Заркави настаивал на объявлении мусульман-шиитов такфирами (вероотступниками), в результате чего они подлежали уничтожению. Это как раз та ситуация, которую мы наблюдаем сегодня, ИГ называет мусульманшиитов рафидами (отказниками). Высшее руководство АК тоже относилось критически к настойчивости аль-Заркави в нападках на шиитов, и когда в 2014 году ИГ объявило захваченную территорию халифатом, Макдиси и другие известные исламисты со связями с АК тоже выразили резкую критику.

Когда аль-Заркави был выпущен из тюрьмы, он создал группу Джунд Аль-Шам, которая вскоре поменяла свое название на Джамаат аль-Таухид валь-Джихад (Единство и Джихад). Еще в 1999 году эта группа была ответственна за несколько попыток совершения террористических действий в Иордании, например, за «Заговор тысячелетия», который был пресечен иорданскими силами безопасности. Аль-Заркави отправился в Афганистан, где он встретился с Усама Бен Ладеном. Его группа не стала частью АК, но Усама Бен Ладен помог аль-Заркави создать тренировочный лагерь в Афганистане в окрестностях города Херат. Когда в 2001 году США напали на Афганистан, группировка аль-Заркави оказывала сопротивление, пока не отошла через Иран и не создала новый лагерь для подготовки в Иракском Курдистане, в тесном сотрудничестве с группировкой Ансар аль-Ислам, которая в то время возглавлялась муллой Крекаром (Фарадж Ахмад Некмеддин). В 1991 году Крекару было предоставлено убежище в Норвегии в качестве беженца из северного Ирака. Однако в 2001 году он оказался в Иракском Курдистане с другими отъявленными джихадистами, связан-

10 Lars Erslev Andersen, "The Locals Strike Back: The Anbar Awakening in Iraq and the Rise of Islamic State," in Reconfiguring Intervention: Complexity, Resilience and the 'Local Turn' in Counterinsurgent Warfare, ed. Louise W. Moe and Marcus-M. Müller (Basingstoke: Palgrave Macmillan, 2017).

11 Кроме публикацией Lister, The Syrian Jihad, изложение истории Иг вдохновлено еще работами William McCants, The ISIS Apocalypse. The History, Strategy, and Doomsday Vision of The Islamic State (New York: St. Martin's Press, 2015); и Fawaz A. Gerges, ISIS. A History (Princeton, NJ: Princeton University Press, 2016).

12 Jakob Skovgaard-Petersen, "Heirs of Abu Bakr: On the Ideology and Conception of History in al-Qaeda and Islamic State," Connections: The Quarterly Journal 16, no. 1 (Winter 2017): 25-36, https://doi.org/10.11610/Connections.16.1.02. 
ными с АК, вместе с которыми он и создал Ансар аль-Ислам. В своей речи в Совете безопасности ООН в феврале 2003 американский государственный секретарь, Колин Пауэлл, упомянул Ансар аль-Ислам и разных джихадистских лидеров, в том числе и Абу Мусаб аль-Сури, когда перечислял причины для иракской войны. Когда была развязана война против Афганистана в октябре 2001 года, многие последователи АК сбежали в Иракский Курдистан и присоединились к Ансар аль-Ислам. Крекар оказался вытесненным недавно прибывшими арабскими ветеранами войны в Афганистане и вернулся в Норвегию через Нидерланды. Аль-Заркави взял в свои руки контроль над этой группой и собрал недавно прибывших джихадистов и иракских повстанцев в Джамаат аль-Таухид валь-Джихад.

Аль-Заркави стал позорно известным за свой экстремизм и жестокость через отвратительные видеозаписи, на которых заложникам отрезали головы и в результате систематических попыток его группировки вызвать гражданскую войну между мусульманами-суннитами и мусульманамишиитами, например осуществляя взрывы в мечетях и святых местах мусульман-шиитов. Распространение видеозаписи, на которой показана экзекуция американского гражданина Николаса Берга в мае 2004 года, потрясла мир как символ жестокости аль-Заркави. Эта запись тревожно напоминает о пресловутых насильственных действиях ИГ, которые мы наблюдаем сегодня. Сегодня аль-Заркави воспринимается и приветствуется ИГ как образец для подражания и как мученик веры. Он играет ту же роль и имеет тот же статус, что имел Усама Бен Ладен в АК. Хотя лидеры АК сильно критиковали нападения аль-Заркави на мусульман-шиитов и предпочли бы, чтобы он направил свои усилия против американцев и коллаборационистского иракского правительства, в октябре 2004 года группировка аль-Заркави официально стала частью сети АК под названием Джихадистский комитет Аль-Каиды в Месопотамии. Эта группа осталась частью АК даже после смерти аль-Заркави. Нынешний конфликт между ИГ и АК был предопределен еще критическим отношением лидеров АК к сектантству аль-Заркави. В 2005 году в руки американских разведывательных служб попало письмо лидера АК аль-Завахири к аль-Заркави. В этом письме Завахири подчеркивает необходимость в обеспечении поддержки местного населения. АК в Месопотамии (Аль-Каида в Ираке, АКИ) не последовала этому совету, наоборот, управляла населенными местами, над которыми имела контроль жестко и догматически, таким образом вызывая отчуждение местного иракского населения. Эта интерпретация идеологии, стратегии и ситуации в Ираке привела к «восстанию снизу» против АК, возглавляемого некоторыми племенными лидерами суннитов и шейхами - движение Анбар (пробуждение).

Аль-Заркави был убит американскими силами в результате целенаправленного удара 7 июня 2006 года на севере от города Бакуба в Ираке. Насилие в Ираке в этом периоде непрерывно и интенсивно разрасталось, особенно в провинции Анбар и вокруг Фалуджи - центра восстания АКИ. 
Конфликт с Аль-Каидой усугубился в результате смерти аль-Заркави, так как его приемник, Абу Хамза аль-Мухаджир, присягнул на верность Абу Омар аль-Багдади, который незадолго до этого был назначен Командиром правоверных (Амир аль-муминин) ИГИ.

ИГИ начало свое существование после того, как Джамаат аль-Таухид валь-Джихад объединила свои силы с другими пятью джихадистскими группами и затем изменила свое название на Исламское государство Ирака. Своей клятвой на верность Абу Хамза подчинил армию АК Исламскому государству в Ираке, что естественно вызвало гнев Усамы Бен Ладена. Этот конфликт не получил публичности, но стал известен из документов, изъятых из дома Усамы Бен Ладена в Абботтабаде после его убийства специальными силами США в 2011 году. Усама Бен Ладен был в ярости, так как АК считала преждевременным объявлять себя государством, поскольку требования для исламского государства только предстояло выполнять. Кроме того, лидер АК был недоволен тем, что Абу Омар аль-Багдади принял на себя командование 12000 боевиками без его одобрения. ИГИ серьезно намеревалось объявить о создании государства, и в этом состоит основное отличие между ИГ и АК. ИГ (ИГИ в то время) хочет учредить исламское государство безотлагательно с использованием насильственных методов, тогда как АК хочет постепенно осуществить создание исламского государства, начиная с нуля, и во главе этого государства должна стоять АК. Можно было бы ожидать, что клятва Абу Хамза на верность Абу Омару Багдади приведет к тому, что ИГИ больше не будет частью АК. Вероятно, так думал и Абу Омар аль-Багдади, но не Усама Бен Ладен и Завахири. ${ }^{13}$

Независимо от этого, ИГИ официально оставалась в составе АК до февраля 2014 года, когда новый лидер АК, аль-Завахири, после затяжного открытого конфликта драматически отверг Абу Бакр аль-Багдади по вопросу о том, кому должен подчиняться лидер Джабхат ан-Нусра. Интересно отметить, что существует прямая связь между аль-Завахири и его разногласиями с АК и разрывом между АК и Исламским государством сегодня. Таким образом, ИГ и АК развивались совсем по-разному после 2006 года. Это особенно хорошо видно в их различных интерпретациях стратегии и образа врага. Поэтому ИГ и Аль-Каиду нельзя рассматривать как одну группировку. У них есть (и всегда были) существенные различия во многих важных областях. Это очевидно из документов из Абботтабада, на которые ссылается аль-Завахири в своей критике ИГ. Тем не менее, наиболее правильно рассматривать ИГ и АК как часть одной и той же организации до момента, когда они сменили название в апреле 2014 года, после конфликта с Завахири, и лидер Фронта ан-Нусра, аль-Джулани, объявил, что Исламское государство в Ираке и Леванте (ИГИЛ) является единственным имеющим силу именем обеих групп. Он, однако, ошибался, поскольку

${ }^{13}$ Lahoud, et al., Letters from Abbottabad. 
Джабхат ан-Нусра, с благословления Завахири, продолжила функционировать под старым названием.

\section{Новая Аль-Каида в Сирии: Джабхат ан-Нусра}

Долгое время, с 2007 по 2010, выглядело так, как будто ИГИ/АКИ будет побеждена и устранена из Ирака. Местные племена были недовольны тем, как АКИ навязывает им свою фундаменталистскую идеологию и контролирует их местные общины и ресурсы. Более того, они подвергались все более массированным ударам правительственной армии в Багдаде и мусульманских шиитских милиций.

Иными словами, они подвергались нападениям на двух фронтах и боялись, что ситуация только ухудшится, если Иран получит еще большее влияние на правительство в Багдаде. В то же время американцы меняли свою стратегию от преследования врага, АКИ, на защиту местного населения. Новый командующий в Ираке, Дэвид Петреус, добился большого успеха благодаря факту совмещения этих двух тенденций. Преследовать АКИ должны были местные люди с поддержкой, подготовкой, оружием и на деньги США. Тогдашнему президенту, Джорджу У. Бушу, советовали вывести войска из Ирака, но вместо этого он увеличил их численность до 20000 и удлинил период пребывания еще дополнительно 10000 военнослужащим, которые иначе вернулись бы в США (так называемая «Волна»). Их задачей была защита местного населения с тем, чтобы завладеть их «сердцами и умами», и подготовка “Сынов Ирака», которых племенные лидеры предоставили американцам для борьбы против АКИ. Численность «Сынов Ирака» составляла 100000 человек, которые воевали за месячную зарплату в 300 долларов США. Операция, названная Анбар Пробуждение, была успешной в смысле, что она заставила АКИ бежать. Большинство ее членов перешло в Сирию, где разведывательные службы уже рассматривали их как угрозу, и потому предприняли жесткие действия против них, отправив их в тюрьму вместе с другими боевиками из сирийских джихадистских центров. ${ }^{14}$

Некоторые из джихадистов успели бежать в Ливан. В 2005 году Сирия была вытеснена из Ливана, но все еще имела важные интересы в этой стране. Джихадисты мигрировали, в частности, в районы северного Ливана вокруг Триполи, где они инфильтрировались в палестинскую группировку, поддерживаемую Сирией, Фатах аль-Ислам, которая в 2007 году в беженском лагере Нахр аль-Барад была ответственна за сопротивление ливанской армии, в результате чего погибли более 400 человек. Когда мятеж был подавлен, некоторые из джихадистов спрятались в лагере палестинских беженцев в Айн аль-Хельвех в южном Ливане, недалеко от города

14 Lars Erslev Andersen, "The Locals Strike Back." 
Саида. ${ }^{15}$ Фронт ан-Нусра и ИГ полагаются на эти сети с разветвлениями в Сирии и в провинции Анбар, где они вербуют боевиков. Это большая проблема для палестинцев в ливанских лагерях, которые не заинтересованы в том, чтобы их связывали с джихадистскими сетями. В более общем плане, это проблема для всего Ливана, так как присутствие этих мусульманских суннитских джихадистских сетей подвергает страну риску переноса гражданской войны из Сирии в Ливан в форме конфронтации с Хезболла, которая воюет на стороне режима Асада. До сих пор ливанской армии вместе с Хезболла удается предотвращать распространение сирийского конфликта в Ливан. Однако, серьезные террористические действия ИГ в Бейруте в ноябре 1915 года свидетельствуют о том, что есть опасность переноса войны в Сирии в Ливан. Ливан принял более 1.5 миллиона сирийских беженцев, и это очевидно создает большое напряжение для такой маленькой страны.

Иракские племена, стоявшие за движением Анбар Пробуждение, в первую очередь были заинтересованы в безопасности и влиянии на багдадское правительство (а не в «умах и сердцах»). Поскольку американцы осуществляли свою новую антиповстанческую стратегию не обеспечив себе лояльность правительства Нури аль-Малики в Багдаде, ситуация перевернулась с ног на голову, когда США вывели свои войска в конце 2011 года. Находясь под влиянием Ирана и шиитской базы своей власти, Малики проводил сектантскую политику, которая препятствовала тому, чтобы сунниты служили в армии и получали должности в Багдаде. Уже в 2010 году, когда партия аль-Иракия, включающая членов из суннитских племен и секуляристских шиитов, выиграла выборы, Малики не допустил ее к власти и тем самым цементировал сектантскую линию. ${ }^{16}$

Результатом этого стала эскалация насилия и множество исламистских групп в составе АКИ вернули себе свое влияние и объединились с другими группами, руководимые офицерами, которых Поль Бремер выкинул на улицу в 2003 году, когда он расформировал армию Саддама Хуссейна. Таким образом, АКИ/ИГИ вернулись в игру. Они систематически восстанавливали свое влияние, например проникая в структуру власти в городах провинции Анбар и начав кампанию террора, ориентированную на тюрьмы, в результате которой сотни членов АК были освобождены. Цель ИГИ состояла в том, чтобы группировка приобрела могущество в Ираке и создала исламское государство, и после 2012 года сила группировки, которую на тот момент следовало бы называть суннитской повстанческой армией, существенно возросла. Бывший лидер Омар Абу аль-Багдади был убит в 2010 году, и его заменил Абу Бакр аль-Багдади, который был выпущен из американской тюрьмы в Ираке, Кемп Букка, в 2009 году. Многие годы новый лидер был участником исламистских сетей и у него была сте-

15 Bernard Rougier, The Sunni Tragedy in the Middle East. Northern Lebanon from alQaeda to ISIS (Princeton, NJ: Princeton University Press, 2015).

16 Lars Erslev Andersen, "The Locals Strike Back." 
пень доктора исламских наук, полученная в Университете Багдада. Совместно с бывшими офицерами разведки и другими членами АК он превратил ИГИ в повстанческую армию, которая благодаря эффективной стратегии, мафиозным методам и жестоким сектантским насилием стала большой угрозой для режима Багдада и для Иракского Курдистана.

Тогда как в Ираке набирало силу ИГИ, в Сирии разгоралась гражданская война. Всего за несколько месяцев ситуация изменилась: демонстрации перешли в эскалацию насилия прежде всего из-за жестокой реакции режима на требования о реформах. Официально режим заявил, что демонстрации были инспирированы террористами извне и те же террористы были причиной насилия. Чтобы самому убедиться в этом, Башар Асад освободил некоторых из исламистов, которых режим заключил в тюрьму после 2007 года и которые были движущей силой в вербовке боевиков из Сирии для Ирака. Подобно тому, как мелкая рыбешка используется в качестве наживки, исламисты были освобождены из заключения для того, чтобы убедить международное сообщество, что причиной насилия являются иностранные террористы и чтобы запугать местное сирийское население. Однако, ситуация сразу же вышла из-под контроля, исламисты быстро воспользовались своей сетью и организовали исламистское повстанческое движение против режима Асада.

В Ираке ИГИ приняло решение открыть сирийский фронт и принять участие в сирийском восстании. Абу Бакр аль-Багдади возложил эту задачу на Абу Мухаммад аль-Джулани, и соответственные действия были профинансированы ИГИ и богатыми сторонниками АК в Кувейте и Катаре. Джулани, который является сирийцем и имел длительную карьеру в ИГИ при альЗаркави, был послан в Сирию еще в августе 2011 года. В Сирии он посетил разные города, охваченные восстанием, и сформировал группировку, которая позже стала фронтом Джабхат ан-Нусра. Джабхат ан-Нусра официально был объявлен джихадистской группировкой, связанной с АльКаидой 23 января 2012 года. Группировка быстро превратилась в сильную организацию, которая привлекала сторонников из района Залива, из Йемена, Северной Африки, США и Европы, в том числе и из Дании. В течение короткого времени Джабхат ан-Нусра превратилась в одну из самых сильных и наиболее важных милиций в сирийской оппозиции. Их идеология была близка к идеологии Аль-Каиды, что не удивительно, учитывая, что в 2011 году ИГИ все еще было официальной частью сети АК. Успех Джабхат ан-Нусра был обусловлен не только строгой дисциплиной, но и хорошей дозой прагматизма. Таким образом, целью борьбы Джабхат ан-Нусра было создание исламского эмирата и в долгосрочной перспективе халифата, который подчинялся бы основанной на Шариате идеологии, включающей систему наказаний худуд (отрезание рук, избиение, порку и т.д.), но эти принципы не должны были строго применяться во время войны. Иными словами, Шариат и худуд могли подождать до будущего эмирата. Лидеры Джабхат ан-Нусра сделали 
выводы из ошибок АК во время восстания против США и новых иракских руководителей после Саддама Хуссейна в ходе войны в Ираке. Вместо того, чтобы вводить строгий кодекс Шариата для граждан деревень, городов и районов под контролем Джабхат ан-Нусра, группировка поставила на первое место безопасность, поставки нефти и горючего в районах, в которых у них находились под контролем такие ресурсы, защиту местных больниц и поликлиник, даже если пациенты и персонал были секуляристскими и не религиозными. Джабхат ан-Нусра не повторила ошибку АК в Ираке; т.е. они не отдалились от местного населения в иракских городах и поселках. Наоборот, Джабхат ан-Нусра восприняла прагматический подход в сознательном стремлении установить хорошие отношения с местным населением в Сирии. В сопротивительных действиях группировка сотрудничала с сирийскими повстанческими милициями, с исламистами, а также с секуляристскими милициями, в том числе со Свободной сирийской армией (ССА), которые были сформированы всего на несколько месяцев раньше, чем Джабхат ан-Нусра. Наряду с дисциплиной и умелым руководством, этот прагматический подход вероятно стал основой успеха Джабхат ан-Нусра как на местном уровне, так и при вербовке боевиков за границей. Имеются сведения, что некоторые боевики присоединились к Джабхат ан-Нусра не по политическим и религиозным причинам, а из-за того, что эта группировка гораздо лучше организована, чем другие повстанческие милиции.

\section{Создание ИГИЛ и конфликт с Аль-Каидой}

Успех Джабхат ан-Нусра стал причиной для всевозрастающего беспокойства лидеров ИГИ, которые из Ирака видели, что в декабре 2012 года сирийское подразделение организации было включено США в перечень террористических организаций, и что его лидер, Джулани, стал самым разыскиваемым человеком в Сирии. Эти два факта были явными признаками силы Джабхат ан-Нусра в сирийском повстанческом движении. Руководители ИГИ, которые вероятно боялись, что Джабхат ан-Нусра превратится в реального соперника, несколько раз попытались, хотя и безуспешно, заставить аль-Джулани публично заявить, что он и Джабхат ан-Нусра находятся под контролем ИГИ и аль-Багдади. Наконец, 8 апреля 2013 года, объясняя разные названия группировки после ее создания Абу Мусаб альЗаркави, лидер ИГИ Абу Бакр аль-Багдади сделал заявление, в котором сказал, что Джабхат ан-Нусра является ответвлением ИГИ. ИГИ создало это группу в качестве фронта в Сирии для подготовки учреждения будущего исламского государства, которое должно охватить северный Ирак и Сирию. С этого момента, обе группировки следует называть ИГИЛ, ни ИГИ, ни Джабхат ан-Нусра уже не будут считаться действующими названиями.

Через два дня аль-Джулани подтвердил, что сформирование ан-Нусра произошло по приказу аль-Багдади, и что оружие, деньги и живую силу анНусра поставляло ИГИ, но что Фронт ан-Нусра, так же как и ИГИ, подчиня- 
ются высшему руководству АК - обе эти группировки являются местными группами АК и потому должны подчиняться ее лидеру, Айману аль-Завахири. Абу Мухаммад аль-Джулани продолжал придерживаться клятвы на верность аль-Завахири и подтвердил, что ничего не изменилось, несмотря на заявление Абу Бакр аль-Багдади, сделанное двумя днями раньше. Это было началом открытого конфликта между сирийской и иракской группировкой АК, все это закончилось необычной конфронтацией между АК и тем, что позже стало известно как Исламское государство. Поставки оружия к Джабхат ан-Нусра были прекращены, и ИГИЛ начало брать под свой контроль склады оружия и районы, в которых Джабхат ан-Нусра имело сильное влияние. Это сопровождалось жестокостями и пренебрежением к сирийской революции. Борьба против режима Башара Асада не была первостепенной задачей. Высочайшим приоритетом было обеспечение контроля над важными районами в Сирии для того, чтобы сохранять сильную позицию в Ираке.

ИГИЛ сосредотачивается напрямую не на борьбе с режимом Асада, а на контроле над областями, начиная с Алеппо, продолжая аграрными районами, стратегическими пунктами и нефтяными ресурсами, и до Ирака. Это означает, что Асад не был заинтересован в нанесении ударов по группировке с использованием боевых самолетов. Некоторое время он даже покупал нефть, которую, строго говоря, группировка крала у сирийского режима. С другой стороны, разные повстанческие милиции сформировали общий фронт против ИГИЛ, которое в Сирии к концу 2013 года оказалось в полной изоляции. Попытки посредничества между ИГИЛ и Джабхат анНусра провалились. Это привело к тому, что 2 февраля 2014 года лидер АК, Айман аль-Завахири, который был инициатором попыток посредничества, официально заявил, что ИГИЛ больше не является частью сети АК из-за своей стратегии и нежелания сотрудничать.

Это было первым, и пока единственным, случаем, когда группа АК исключалась из сети, и декларация Аль-Завахири стала причиной некоторого переполоха в международных СМИ и была преподнесена под такими заголовками, как «Кто такие ИГИЛ? Террористическая группировка оказалась слишком экстремистской даже для Аль-Каиды» (Гардиан, июнь 2014). Пойдя на разрыв с Аль-Каидой, ИГИЛ ввязалось в открытую войну со всей сирийской оппозицией, в том числе с Фронтом ан-Нусра. Однако, в действительности ИГИЛ стала намного сильнее, чем вялое старое высшее руководство АК. Конфликт на короткое время привел к внутреннему разделению в Джабхат ан-Нусра, выразившемуся в том, что несколько членов, более тесно связанные с аль-Багдади, чем с аль-Джулани, ушли из анНусра и присоединились к ИГИЛ. Ко времени, когда конфликт между АК и ИГИЛ стал публичным, ИГИЛ в значительной степени потеряло свое влияние в Сирии благодаря объединению сил других оппозиционных групп. Однако, в течение января и февраля 2014 года, ИгИЛ произвело перегруппировку и быстро захватило контроль над стратегически важными зонами 
с большими ресурсами в провинции Дейр-Эзсор. Весной 2014 года группировка восстановила свои позиции в восточном Алеппо и консолидировала свои силы в Ракке - главном городе группировки в Сирии.

Расширение территорий в Сирии мотивировалось не только борьбой против Асада, но его целью было противодействовать ослаблению того, что в июне 2014 года стало известно как Исламское государство. Общей задачей ИГ было завершение широкой суннитской революции против правительства Ирака с целью создать халифат, который по историческим и религиозно-апокалиптическим причинам должен охватывать территорию вокруг города Дабик в северной Сирии, так как древние религиозные писания предсказывают, что это и есть место, где произойдет последняя битва. Расширение происходило в то же самое время, когда ИгИЛ захватило контроль над Фалуджой и произвело осаду города Рамади в иракской провинции Анбар. Таким образом, весной 2014 года ИГИЛ быстро укрепило свои позиции и в Ираке, и в Сирии.

10 июня 2014 года ИГИЛ неожиданно для всех оккупировало город Мосул. По телевизору это выглядело, как будто разгулявшиеся орды джихадистов прогоняют большую и хорошо вооруженную иракскую армию, и сразу же возник вопрос: как такая группа, предположительно состоящая из 3000-5000 мужчин, донимала и в итоге нанесла поражение целой хорошо вооруженной армии? Некоторые медиа сообщали, что всего 800 джихадистов обратили в бегство 30000 солдат (пять дивизий). Однако сила ИГИЛ вряд ли была такой уж большой неожиданностью, имея в виду успехи группировки ранее в этом году как в Ираке, так и в Сирии, и не на последнем месте учитывая, что в течение многих лет группа систематически консолидировала свои силы в суннитских городах в Ираке и приобрела возрастающую поддержку со стороны суннитских мусульманских групп и со стороны народа. Как было сказано ранее, местные иракские журналисты и аналитики в течение долгого времени писали, как ИГИ захватило контроль над Мосулом, используя террористические и мафиозные методы. Иными словами, ИГИЛ смогло столь легко захватить такой большой город как Мосул потому, что группировка уже контролировала большую часть города и террористическими методами захватила оружейные, денежные, деловые и обслуживающие сети.

ИГИЛ является не только салафистской фундаменталистской группой, но по крайней мере с 2010 года, хорошо управляемой организаций, поддерживаемой многими суннитскими милициями, с эффективной стратегией и идеологией строительства сплоченного исламского государства, которое может функционировать по всем показателям. Это, похоже, привлекательно для многих людей в этом регионе, в Европе и по всему миру, так как в Сирию и Ирак слетается рекордное количество добровольцев. То, что мы наблюдали в Ираке с ответвлениями в Сирии, это было суннитское повстанческое движение, которое не ограничивалось жестоким Исламским государством, а имело гораздо более широкую поддержку со сторо- 
ны других, в том числе нерелигиозных групп, которые чувствовали себя полностью забытыми правительством в Багдаде, региональным правительством Курдистана в Ираке, режимом Асада в Сирии, США и международным сообществом.

\section{Фронт ан-Нусра и ИГ}

Джабхат ан-Нусра быстро восстановился от регресса в результате конфликта с ИГ, при котором Фронт стал свидетелем того, как большое число его боевиков присоединилось к войскам аль-Багдади. Джабхат ан-Нусра быстро восстановил свои позиции, и к группировке присоединились новые рекруты. Джабхат ан-Нусра так же смог войти в сотрудничество с другими сирийскими повстанческими милициями, в частности с Ахрар аль-Шам, и иногда с ССА. Как было упомянуто выше, в декабре 2012 года Фронт анНусра был включен США в список террористических организаций, и в сентябре 2015 года ЦРУ объявило, что Фронт ан-Нусра сформировал группу «Хорасан», название, используемое ЦРУ для обозначения группы ветеранов АК, которые присоединились к Фронту ан-Нусра в Сирии, прибыв из Йемена и Афганистана, и которые, по сведениям разных источников, теперь скрываются в провинции Идлиб. С сентября 2015 года ан-Нусра является объектом атак США. Вместе с Францией американцы придерживаются мнения, что Джабхат ан-Нусра является одной из группировок АК, а потому не может участвовать в переговорах о будущем Сирии. Несмотря на это, ан-Нусра продолжает придерживаться прагматического подхода, направленного на поражение режима Асада, и все говорит о том, что стратегия ан-Нусра будет успешной в том смысле, что группа усиливает свои позиции и приобретает более широкую поддержку в этой борьбе. В то же время, лидер ан-Нусра, аль-Джулани, заявляет, что о сотрудничестве, или даже примирении с ИГ не может быть и речи. Лидер АК, Завахири, несколько раз взывал к милициям в Сирии перестать воевать друг с другом и сосредоточиться на войне с режимом Дамаска. Во время тяжелых боев вокруг палестинского беженского лагеря Ярмук в Дамаске ИГ и ан-Нусра воевали совместно против сил сирийского правительства, которое поддерживают палестинские милиции под командованием Ахмада Джибрил из НФОП-ГК. Поэтому имели место спекуляции, что, возможно, ан-Нусра и ИГ сближаются.

С учетом всех обстоятельств можно сказать, что боевики Фронта анНусра перешли на другую сторону. Джабхат ан-Нусра выросла из ИГ, и некоторые его члены, возможно, чувствуют себя связанными сильнее с альБагдади, чем с аль-Джулани, особенно если возникают обстоятельства, способствующие этому. Мы, вероятно, будем свидетелями и других таких сдвигов, но по существу нет никаких сигналов, что ан-Нусра и ИГ пытаются сблизиться. Но слухи об этом ходят. В журнале «Foreign Affairs» известный исследователь по вопросам терроризма, профессор университета Джорджтауна, Брюс Хоффман, приводит четыре довода в пользу гипотезы, 
что ИГ и АК объединятся во взрывоопасный коктейль. Но на данный момент такое развитие событий отвергается самими сторонами как чистая спекуляция.

Хотя США и, возможно, Франция наносили бомбовые удары по Фронту ан-Нусра в Сирии, Джабхат ан-Нусра выигрывает от того, что международная кампания направлена в основном против ИГ. АК, похоже, сделала выводы из своих ошибок. Вместо того, чтобы навязывать свою интерпретацию Корана и Шариата местному населению в Сирии, АК применяет более долгосрочный подход и работает над тем, чтобы стать частью общества для того, чтобы получить его поддержку. Если политическая, экономическая и силовая ситуация не изменится радикальным образом, будут преобладать условия, позволяющие таким группировкам и сетям, как ИГ и АК, возвращаться снова и снова, подобно кротам в садах Тиволи в Копенгагене. Для того, чтобы эффективно бороться с воинственными джихадистскими сетями, важно понимать исторические, социальные и политические обстоятельства, которые порождают такие группировки, как АК и ИГ, и заниматься этими проблемами. До нынешнего времени война против терроризма в этом не преуспевает.

Весной 2016 года появилось несколько отчетов, в которых утверждается, что ИГ испытывает затруднения в военном и в экономическом плане. Основные города, Мосул, Фалуджа и Ракка находятся под осадой, и в финансовом плане ИГ во все большей степени лишается доходов от продажи нефти. Тем не менее, ИГ далеко не сломлено. Даже если ИГ будет побеждено в обозримом будущем, сети джихадистов, которые были созданы в этом регионе от Ливана до Сирии и Ирака, все равно останутся, так же как и проблемы, которые являются в большой степени основой для повстанческих движений и сектантских конфликтов.

\section{Заключение: ИГ, АК и «Тридцатилетняя война» на Ближнем Востоке}

Необходимы решительные политические перемены как в Ираке, так и в Сирии, для того, чтобы новые стабильные правительства смогли создать для сирийцев и иракцев общество, основанное на верховенстве закона и безопасности. Это единственное условие для эффективной борьбы с экстремизмом в этом регионе. Как мы видели в 2014 году, победа над ИГ в Сирии и в Ираке начинается в Дамаске и Багдаде. В этом плане администрация Джорджа У. Буша и его нео-консервативные советники были правы: нужна смена режима! Однако решение не состоит в том, чтобы, как хотел Буш, пробомбить демократию на Ближнем Востоке, или, как думают сейчас, разбомбить ИГ, не думая о том, что делать дальше. Нет сомнения, что объединенный мир победит ИГ и уничтожит халифат. Весной 2016 года было много сигналов и много разговоров о том, что ИГ испытывает затруднения. Однако по мере вытеснения ИГ, группировка аль-Багдади занимает позиции в таких регионах, как Афганистан и Ливия, в которых Запад уже 
вел войны. Не нужно большого воображения, чтобы увидеть, что нынешняя стратегия, в соответствии с которой Запад и Дания включились в «Тридцатилетнюю войну» на Ближнем Востоке, является сизифовым проектом, который настолько же перспективен, как и прихлопывание кротов колотушкой в садах Тиволи.

\section{6 авторе}

Ларс Эрслев Андерсен является старшим научным сотрудником ДИМИ. До этого был доцентом по истории в Университете Южной Дании (УЮД) и руководителем Исследовательского центра по проблемам Ближнего Востока при УЮД. Предметом его исследований являются взаимосвязи между Мировым порядком и Войной с терроризмом, политика безопасности США в отношении Ближнего Востока, повстанческое движение в Ираке и политические последствия кризиса с беженцами в Леванте. В число его последних публикаций входят работы “The Locals Strike Back: The Anbar Awakening in Iraq and the Rise of Islamic State," в Reconfiguring Intervention: Complexity, Resilience and the 'Local Turn' in Counterinsurgent Warfare, ed. Louise W. Moe and Marcus-M. Müller (Basingstoke: Palgrave Macmillan, 2017) и The Neglected. The Palestine Refugees in Lebanon and the Syrian Refugee Crisis, DIIS Report 2016:12 (Copenhagen and Beirut, 2016). 